\title{
AREA 5 SITE CHARACTERIZATION PROJECT REPORT FY 1994
}

\author{
by \\ William Albright \\ Scott Tyler \\ Jenny Chapman \\ Mary Miller \\ Rocio Estrella \\ Water Resources Center \\ Desert Research Institute \\ University and Community College System of Nevada
}

\author{
prepared for \\ Nevada Operations Office \\ U.S. Department of Energy \\ Las Vegas, Nevada
}

September 1994

\section{DISCLAIMER}

This report was prepared as an account of work sponsored by an agency of the United States Government. Neither the United States Government nor any agency thereof, nor any of their employees, makes any warranty, express or implied, or assumes any legal liability or responsibility for the accuracy, completeness, or usefulness of any information, apparatus, product, or process disclosed, or represents that its use would not infringe privately owned rights. Reference herein to any specific commercial product, process, or service by trade name, trademark, manufacturer, or otherwise does not necessarily constitute or imply its endorsement, recommendation, or favoring by the United States Government or any agency thereof. The views and opinions of authors expressed herein do not necessarily state or reflect those of the United States Government or any agency thereof.

The work upon which this report is based was supported by the U.S. Department of Energy under Contract \#DE-AC08-90NV10845.

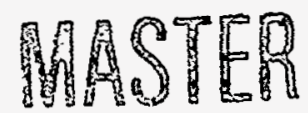




\section{DISCLAIMER}

Portions of this document may be illegible in electronic image products. Images are produced from the best available original document. 


\section{CONTENTS}

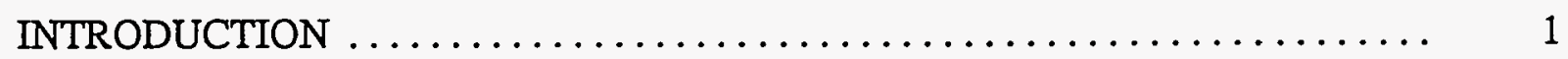

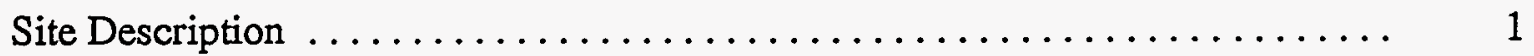

LABORATORY TESTING METHODS $\ldots \ldots \ldots \ldots \ldots \ldots \ldots \ldots \ldots \ldots \ldots \ldots \ldots$

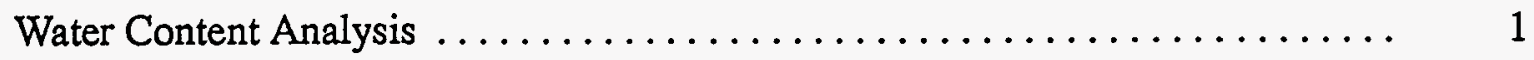

Soil Bulk Density .................................... 1

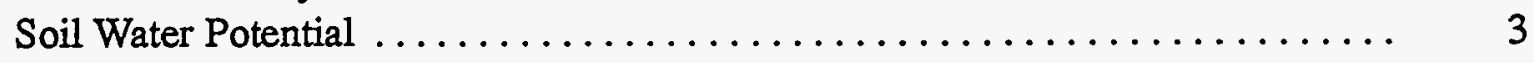

Soil Water Extraction ................................ 4

Soil Water Extract Isotope Analysis $\ldots \ldots \ldots \ldots \ldots \ldots \ldots \ldots \ldots \ldots \ldots \ldots, 4$

Oxygen Isotope Analysis . . . . . . . . . . . . . . . . . . . . . .

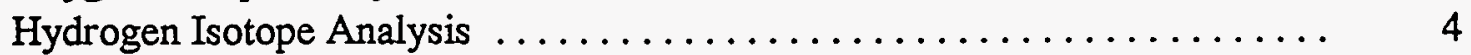

${ }^{13} \mathrm{C}$ Analysis ...................................... 4

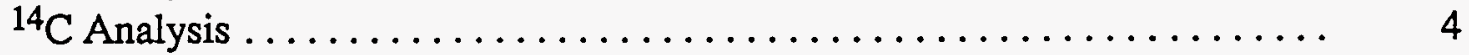

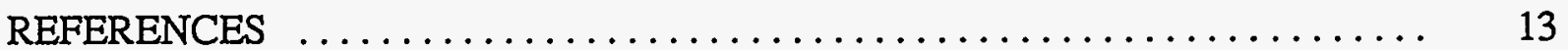

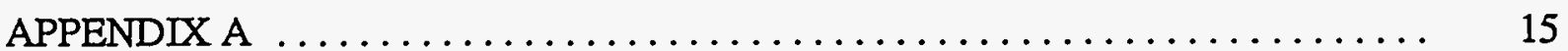

A.1. Physical and hydrologic data for RP-1. . . . . . . . . . . . . .

A.1. Physical and hydrologic data for RP-2 $\ldots \ldots \ldots \ldots \ldots \ldots \ldots \ldots \ldots . \ldots \ldots$

A.1. Physical and hydrologic data for AP-1. . . . . . . . . . . . . . . . . 18

A.1. Physical and hydrologic data for AP-2 . ................... 19

A.1. Physical and hydrologic data for $\mathrm{NN}-1$ and $\mathrm{NW}-2 . \ldots \ldots \ldots \ldots \ldots .20$

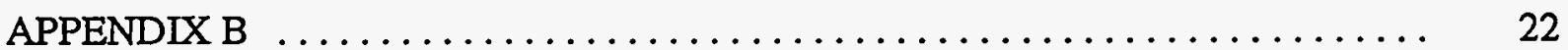

B.1. Stable isotope data for boreholes. $\ldots \ldots \ldots \ldots \ldots \ldots \ldots \ldots \ldots \ldots .23$

\section{FIGURES}

1. Location of the Area 5 Radioactive Waste Management Site (RWMS)

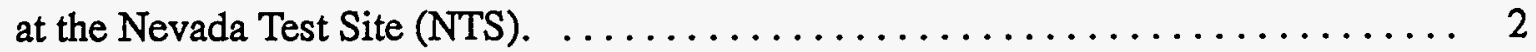

2. Location of recently completed and sampled boreholes in Area 5 of the NTS. ..... 3

3. Depth profile of total soil water potential $(\mathrm{KPa})$ for borehole AP-1. . . . . . . . 5

4. Depth profile of volumetric water content for borehole AP-1 ............ 5

5. Depth profile of total soil water potential $(\mathrm{KPa})$ for borehole AP-2. $\ldots \ldots \ldots \ldots 6$

6. Depth profile of volumetric water content for borehole AP-2. ............ 6

7. Depth profile of total soil water potential $(\mathrm{KPa})$ for borehole $\mathrm{RP}-1 . \ldots \ldots \ldots \ldots 7$

8. Depth profile of volumetric water content for borehole RP-1. . . . . . . . . 7

9. Depth profile of total soil water potential $(\mathrm{KPa})$ for borehole $\mathrm{RP}-2 . \ldots \ldots \ldots \ldots 8$

10. Depth profile of volumetric water content for borehole RP-2. . . . . . . . . 8 
11. Depth profile of total soil water potential $(\mathrm{KPa})$ for borehole $\mathrm{NN}$. . . . . . . . 9

12. Depth profile of volumetric water content for borehole NN. ........... 9

13. Depth profile of total soil water potential $(\mathrm{KPa})$ for borehole $\mathrm{NW} . \ldots \ldots \ldots$

14. Depth profile of volumetric water content for borehole $N W \ldots \ldots \ldots \ldots$ 


\section{INTRODUCTION}

The Area 5 Site Characterization Project is designed to determine the suitability of the Radioactive Waste Management Site (RWMS) for disposal of low-level waste (LLW), mixed waste (MW) and transuranic waste (TRU). The Desert Research Institute (DRD) has conducted this study for the Area 5 Site Characterization Project for the U.S. Department of Energy, Nevada Operations Office (DOE/NV), Waste Management Division (WMD). The purpose of DRI's Area 5 Site Characterization Project is to characterize important properties of the upper vadose zone which influence infiltration and redistribution of water and transport of solutes as well as to characterize the water quality and hydrologic conditions of the uppermost aquifer.

This report describes methods and presents a summary of all data and results from laboratory physical and chemical testing from borehole samples through September 1994. DRI laboratories performed soil water content, soil water potential, soil bulk density, and soil water extract isotope analyses.

\section{Site Description}

Area 5 is located in the southeast quarter of the Nevada Test Site (NTS) and is one of two areas at the NTS designated as Radioactive Waste Management Sites (RWMS) (Figure 1). The Area 5 RWMS encompasses $2.96 \mathrm{~km}^{2}$ on an alluvial fan within the Frenchman Flat drainage basin. Area 5 averages $11.7 \mathrm{~cm}$ of precipitation annually, and the vadose zone is approximately $240 \mathrm{~m}$ thick (Winograd and Thordarson, 1975). In addition to the existing pilot wells and science trench boreholes, eight additional boreholes were recently completed: air permeability test boreholes (AP 1 and 2), random pumping test boreholes (RP 1 and 2), and neutron access boreholes (NN-1, NE-1, NS-1, and NW-1). Figure 2 shows the locations of these new boreholes.

\section{LABORATORY TESTING METHODS}

A brief description of the laboratory testing methods and references used to obtain the data contained in this report are presented here. Detailed methods can be found in DRI Quality Assurance Standard Operating Procedures (SOPs).

\section{Water Content Analysis}

Soil water content refers to the amount of water contained in a unit mass or volume of soil. The fractional content of water in the soil can be expressed in terms of either mass $\left(\mathrm{kg} \mathrm{kg}^{-1}\right)$ or volume $\left(\mathrm{m}^{3} \mathrm{~m}^{-3}\right)$. The traditional gravimetric method of measuring mass wetness consists of determining a sample's moist and dry weights. The moist weight is determined by weighing the sample at the time of sampling and the dry weight is obtained after drying the sample to a constant weight. The standard method of drying the soil consists of drying the samples in an oven at $105^{\circ} \mathrm{C}$ for 24 hours (Hillel, 1982). The mass wetness (w) or gravimetric wetness $\left(\theta_{m}\right)$ is the ratio of the weight loss in drying to the dry weight of the sample. If the bulk density of the sample is known, the volumetric water content $\left(\theta_{\mathrm{v}}\right)$ can also be determined.

\section{Soil Bulk Density}

Soil bulk density, $\mathrm{Q}_{\mathrm{b}}$, is the ratio of the mass of dry solids to the bulk volume of the soil. The mass is determined after drying to constant weight at $105^{\circ} \mathrm{C}$, and the volume of the sample as taken 


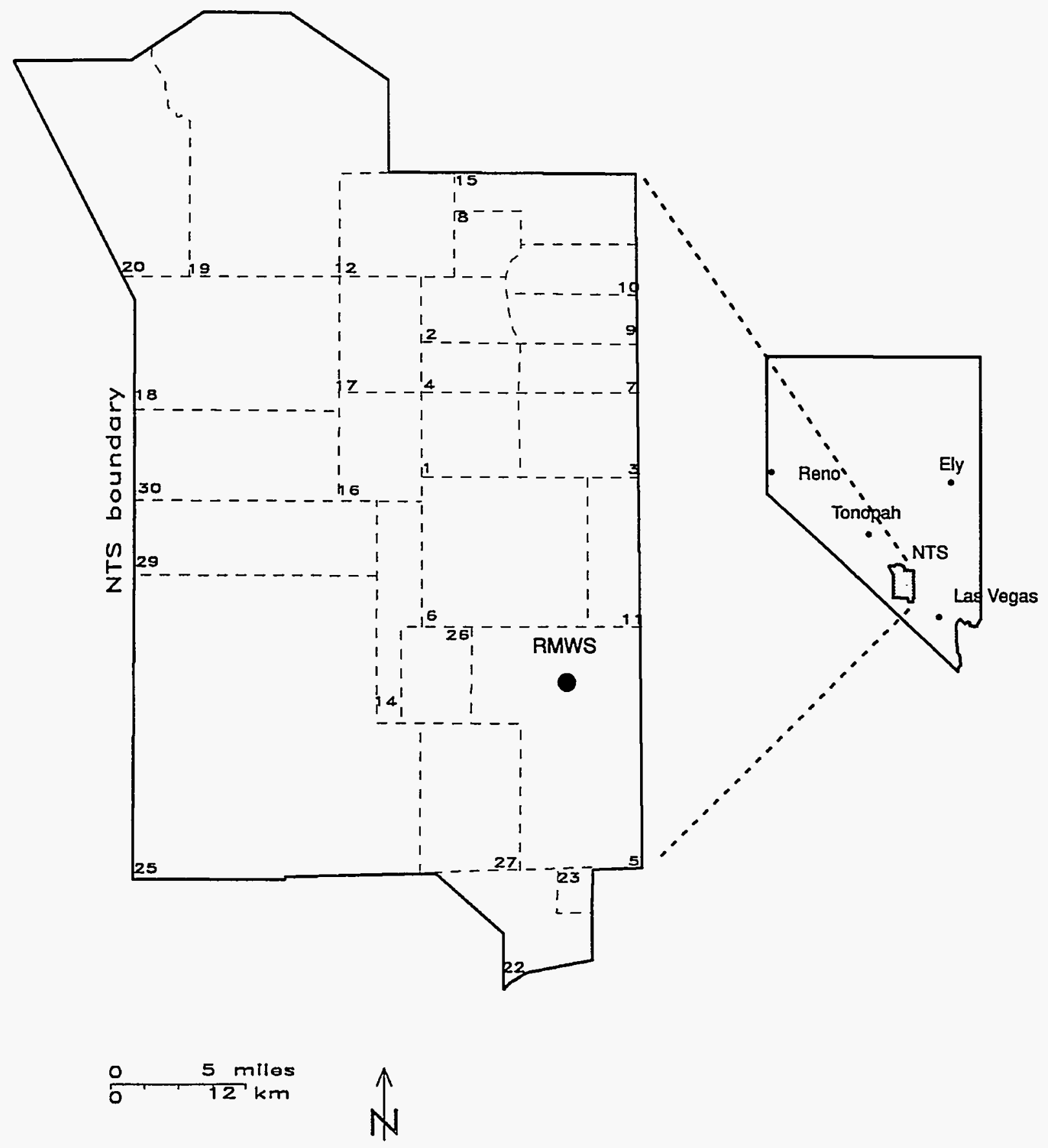

Figure 1. Location of the Area 5 Radioactive Waste Management Site (RWMS) at the Nevada Test Site (NTS). 


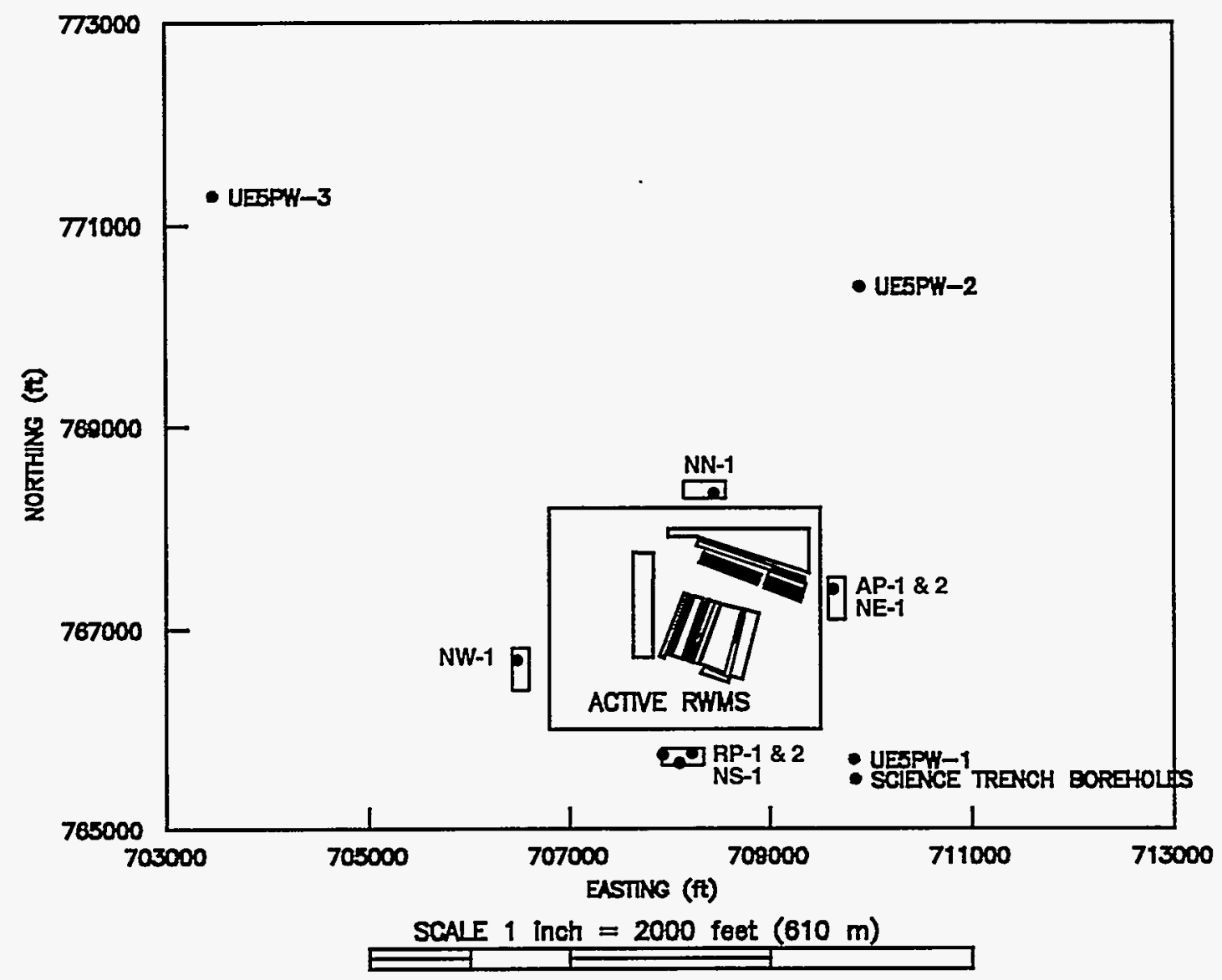

Figure 2. Location of recently completed and sampled boreholes in Area 5 of the NTS.

in the field (Blake and Hartge, 1986). Bulk density was determined only on core samples with 100 percent recovery.

\section{Soil Water Potential}

Soil water can contain energy in different quantities and forms. The potential energy, caused by position or internal conditions, is of primary importance in determining the state and movement of water in the soil (Hillel, 1982). All forms of water transfer occur as a result of potential differences with movement from regions of higher to lower potential. The concept of soil water potential refers to the relationship between the retention of water by soil and the soil water energy level.

All methods for measuring water potential in soils require that some medium, whose water potential can be determined, be in equilibrium with soil water. The soil water potential is then found from the known water potential of the medium (Campbell and Gee, 1986). Soil water potential for the Area 5 Project is being determined via (1) filter paper and (2) a CX-2 water activity meter. For the first method, filter paper is used as a standard matrix and equilibrated with soil water to calculate soil water potential (Graecen et al., 1989). The CX-2 water activity meter uses a cooled mirror to 
sense the dew point of water vapor in a closed chamber containing a soil sample. Dew-point-derived water activities are converted to total water potential using the Kelvin equation (Gee et al., 1992).

The CX-2 method was used on all samples below a water potential of $-0.5 \mathrm{MPa}$. For the year ending September 1994, all soil water potential measurements were made with this method.

\section{Soil Water Extraction}

Azeotropic distillation with toluene is used to extract soil water for oxygen and hydrogen isotopic analysis. The method used by the DRI Environmental Isotope Laboratory in Las Vegas is a modification of the methods used by Revezs and Woods (1990) and Ingraham and Shadel (1992). The method is based on the fact that water and toluene form an azeotropic mixture at $84.1^{\circ} \mathrm{C}$, but are immiscible at ambient temperature.

\section{Soil Water Extract Isotope Analysis}

\section{Oxygen Isotope Analysis}

Samples for oxygen isotope analysis are prepared using the guanidine hydrochloride method modified after Dugan et al. (1985). In this method, $10 \mu \mathrm{l}$ of water are frozen into a glass reaction tube containing excess guanidine hydrochloride. The tube is then sealed at the top by melting in a torch flame. Through a series of reactions, the water is quantitatively converted into $\mathrm{CO}_{2}$ gas. This gas is purified and analyzed on a Finnigan Model Delta-E gas-ratio mass spectrometer.

\section{Hydrogen Isotope Analysis}

Samples for hydrogen isotope analysis are prepared using the zinc-reduction method modified after Kendall and Coplen (1985). In this method, $10 \mu \mathrm{l}$ of water are frozen and sealed into a $7 \mathrm{~mm}$ glass reaction tube containing $0.25 \mathrm{~g}$ of zinc metal shot. The water and zinc are reacted in a furnace at $450^{\circ} \mathrm{C}$ for one hour to produce hydrogen gas which is directly analyzed on a Nuclide Model 30/60/HD Mass Spectrometer (Gonfiantini, 1981).

\section{$\underline{13 \text { C Analysis }}$}

Samples analyzed for ${ }^{13} \mathrm{C}$ were precipitated in the laboratory as strontium carbonate and prepared by the phosphoric acid method as described by McCrea (1950), and the resulting carbon dioxide gas was also analyzed in the Finnigan-Matt mass spectrometer for ${ }^{13} \mathrm{C} /{ }^{12} \mathrm{C}$ ratios.

\section{$\underline{14}$ C Analysis}

${ }^{14} \mathrm{C}$ samples were sent to the Lawrence Livermore National Laboratory Center for accelerator mass spectrometry. 


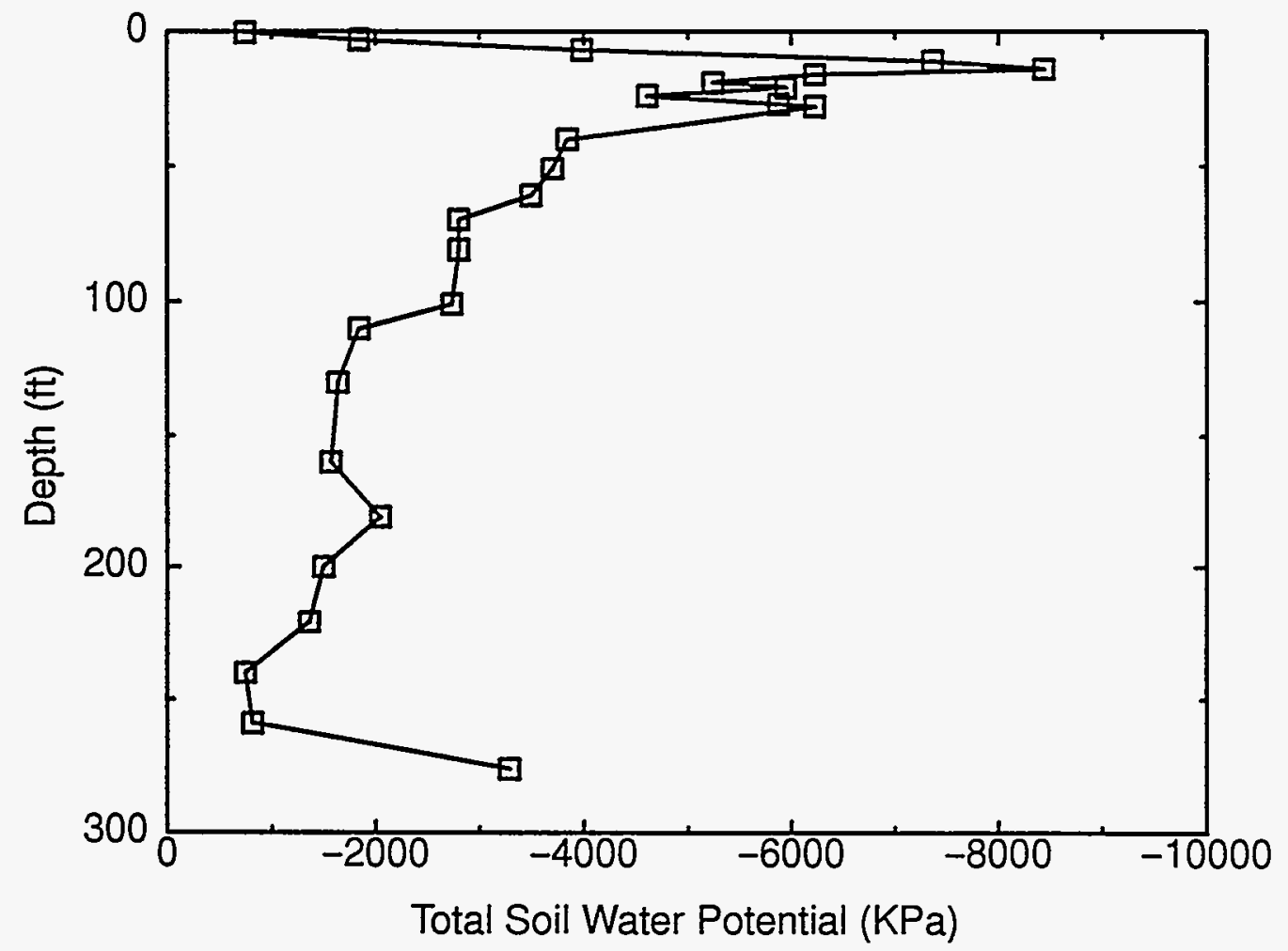

Figure 3. Depth profile of total soil water potential (KPa) for borehole AP-1.

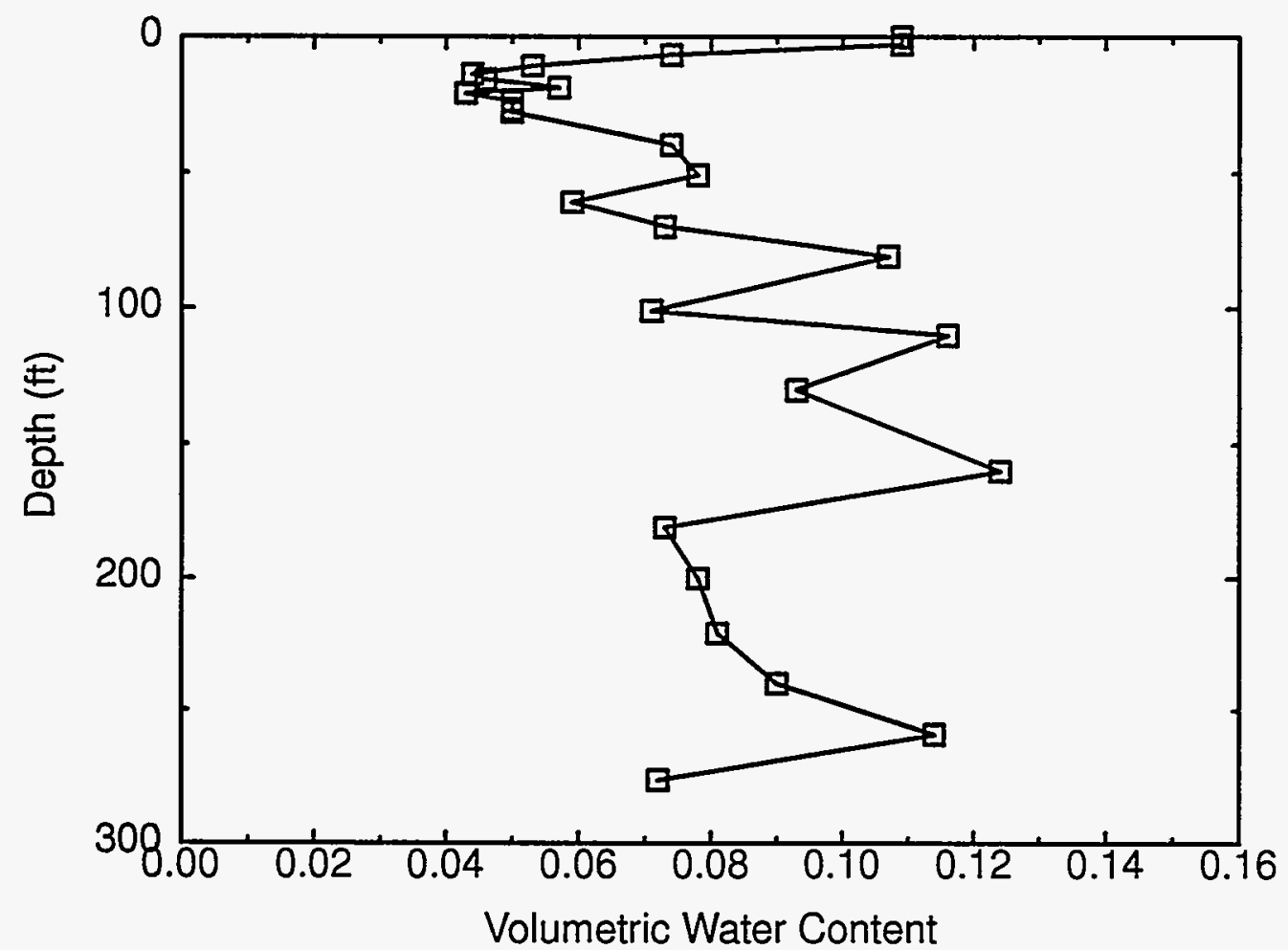

Figure 4. Depth profile of volumetric water content for borehole AP-1. 


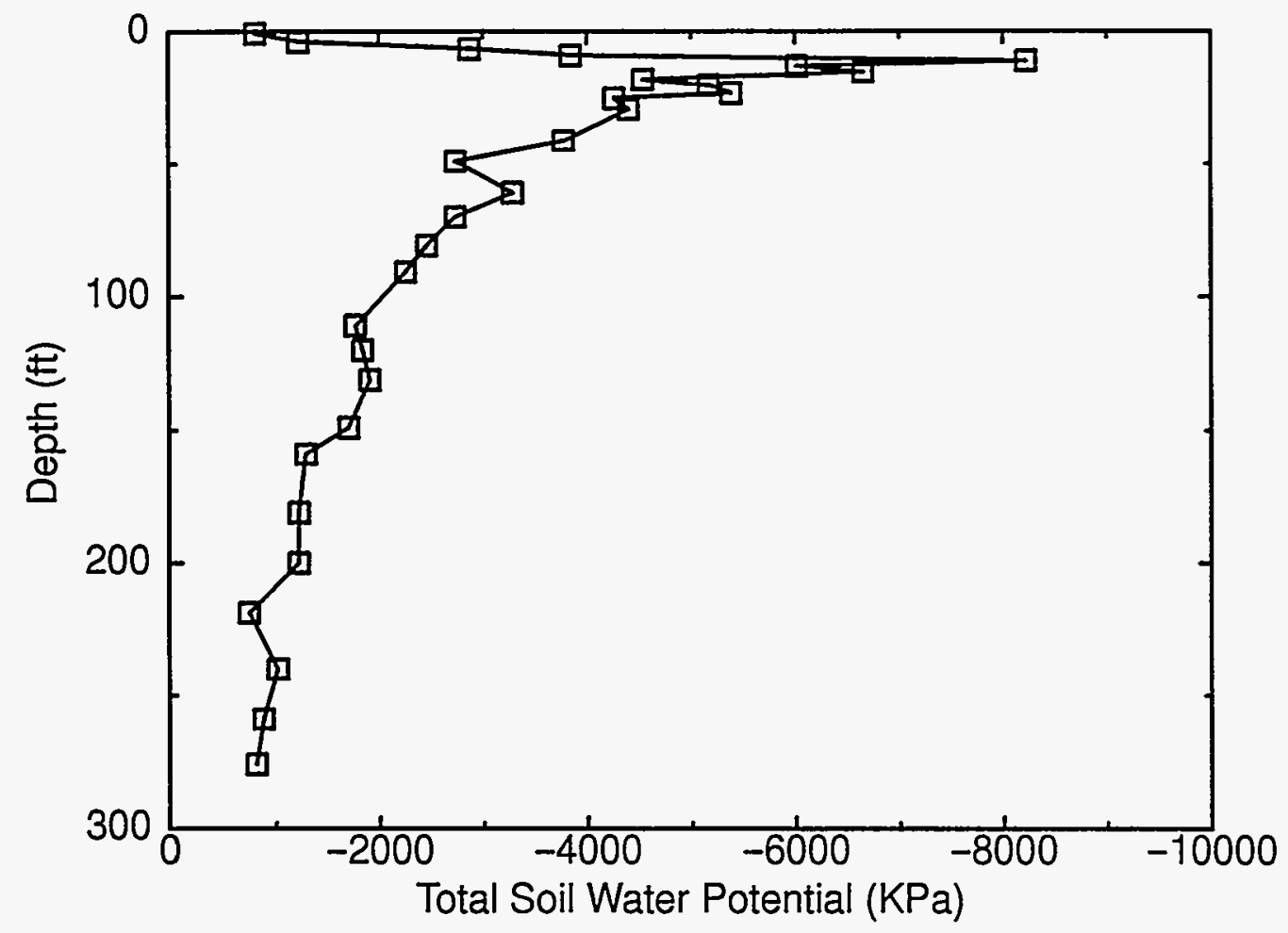

Figure 5. Depth profile of total soil water potential $(\mathrm{KPa})$ for borehole AP-2.

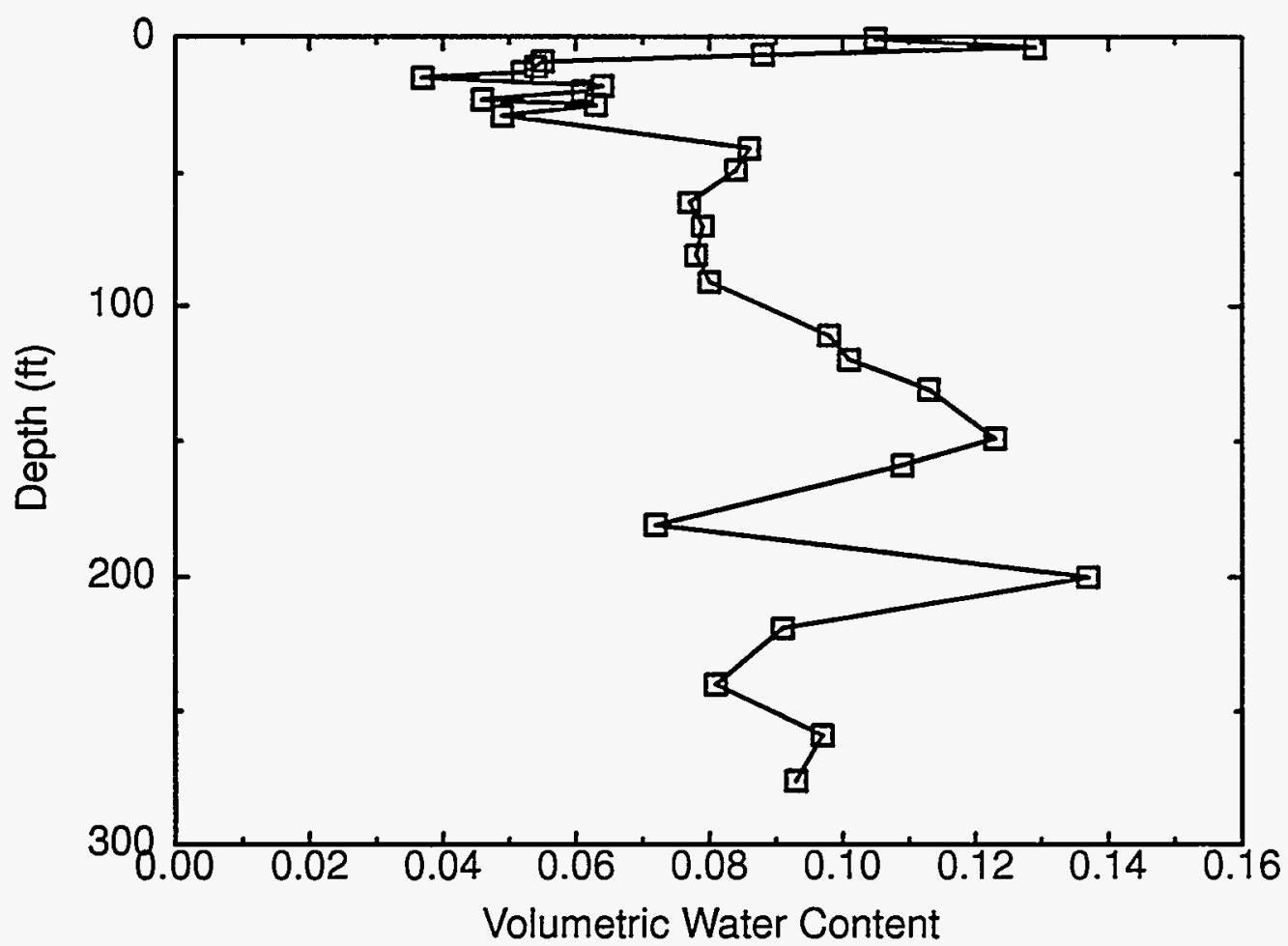

Figure 6. Depth profile of volumetric water content for borehole AP-2. 


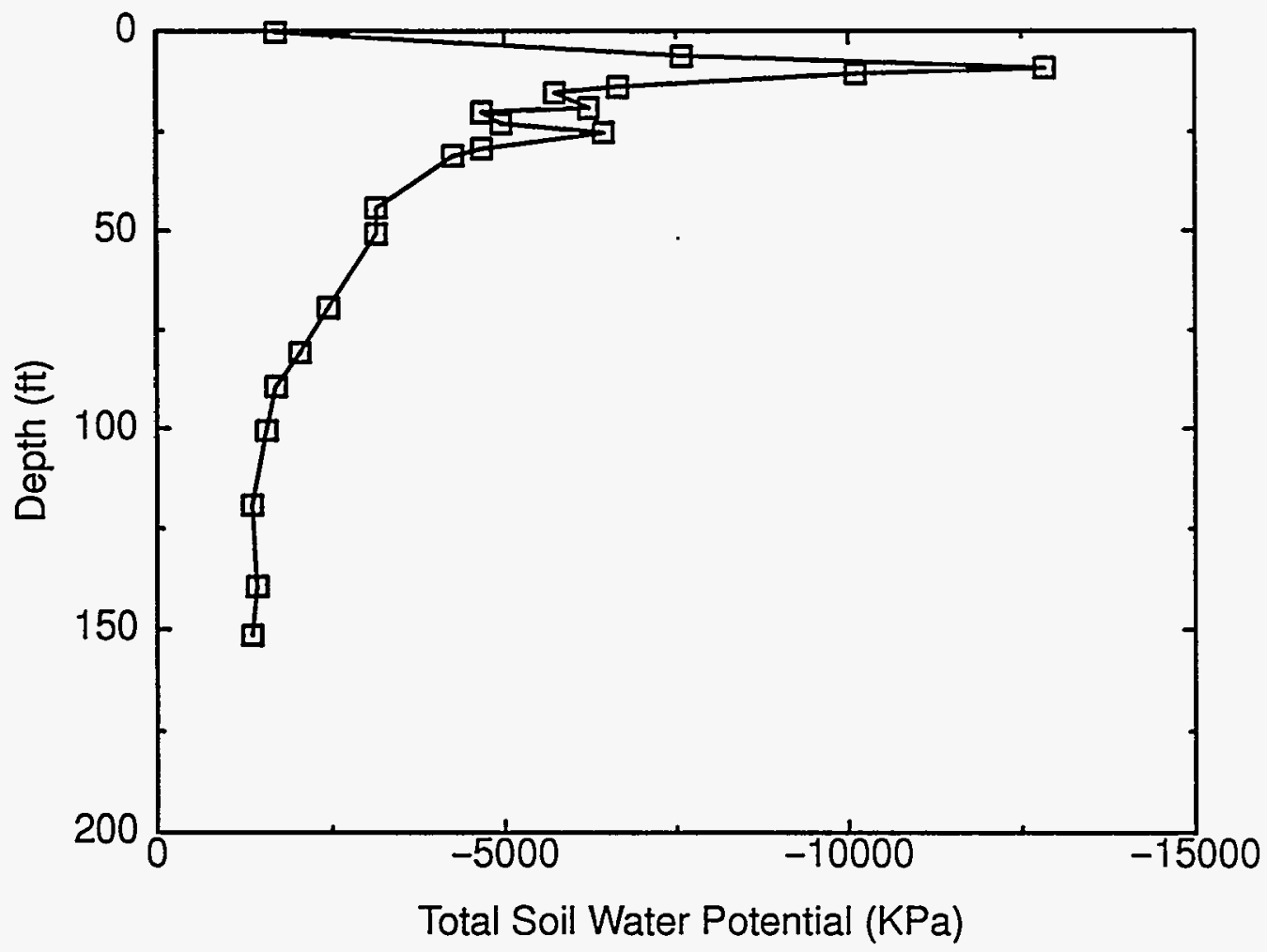

Figure 7. Depth profile of total soil water potential (KPa) for borehole RP-1.

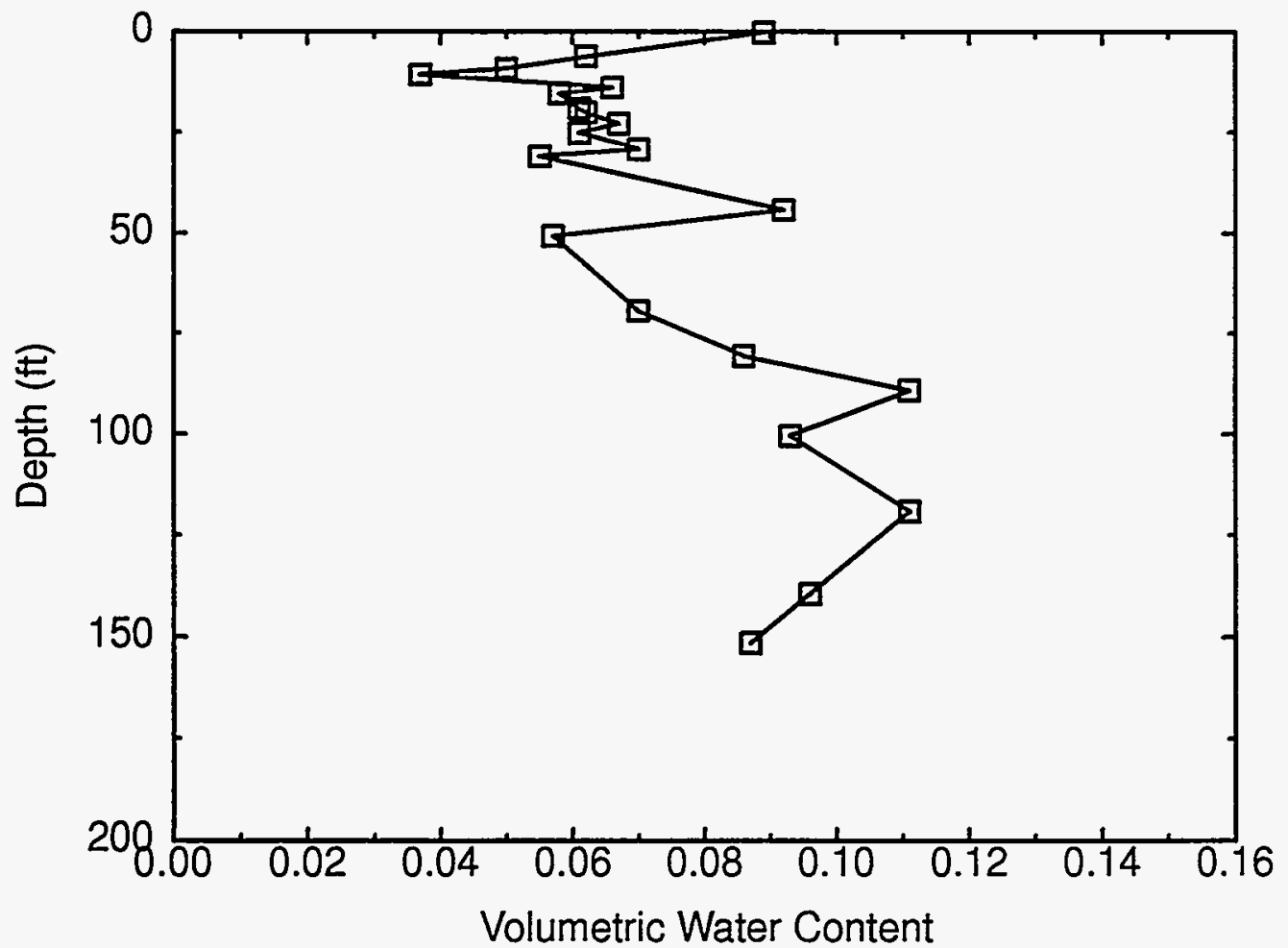

Figure 8. Depth profile of volumetric water content for borehole RP-1. 


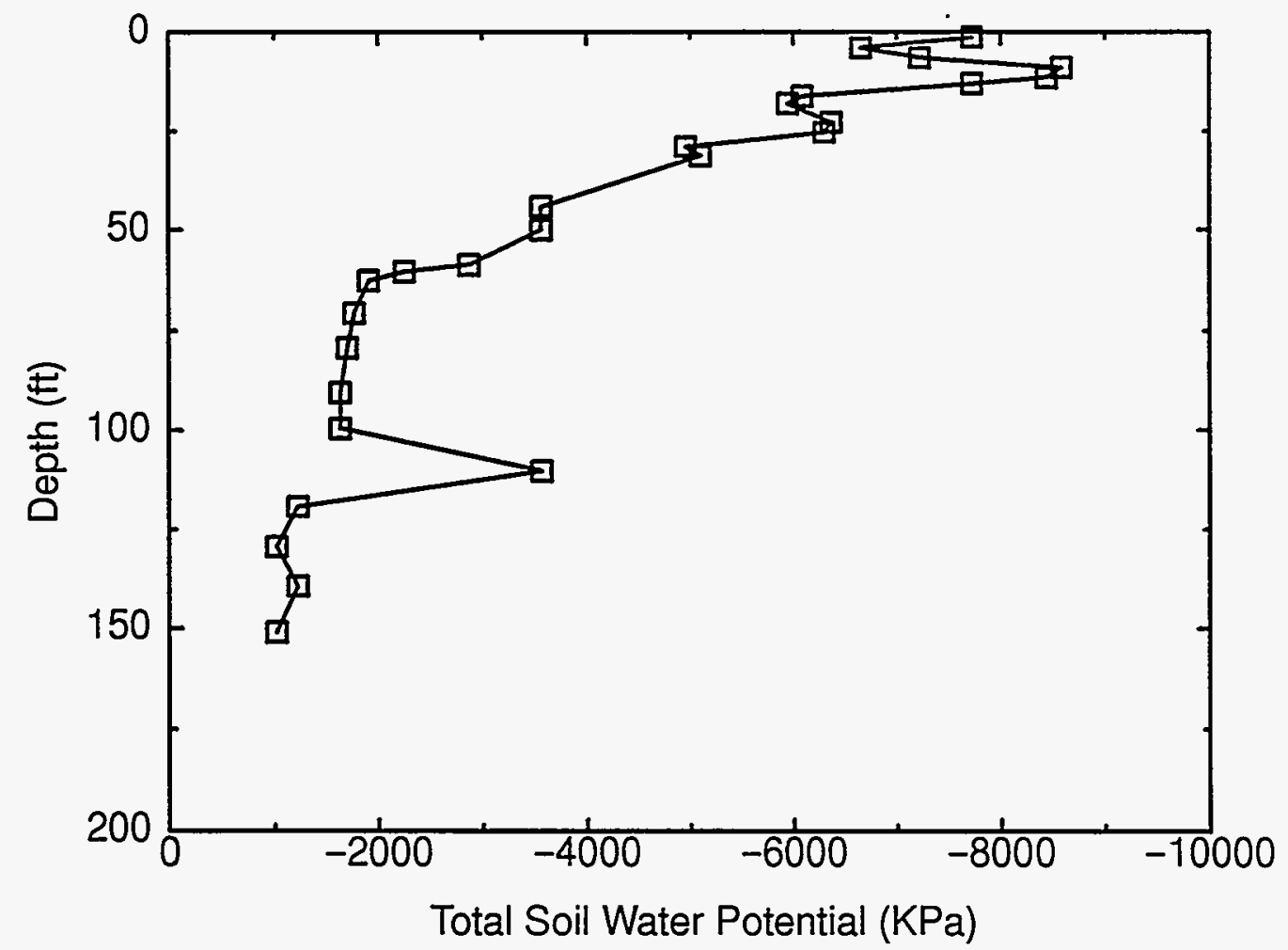

Figure 9. Depth profile of total soil water potential (KPa) for borehole RP-2.

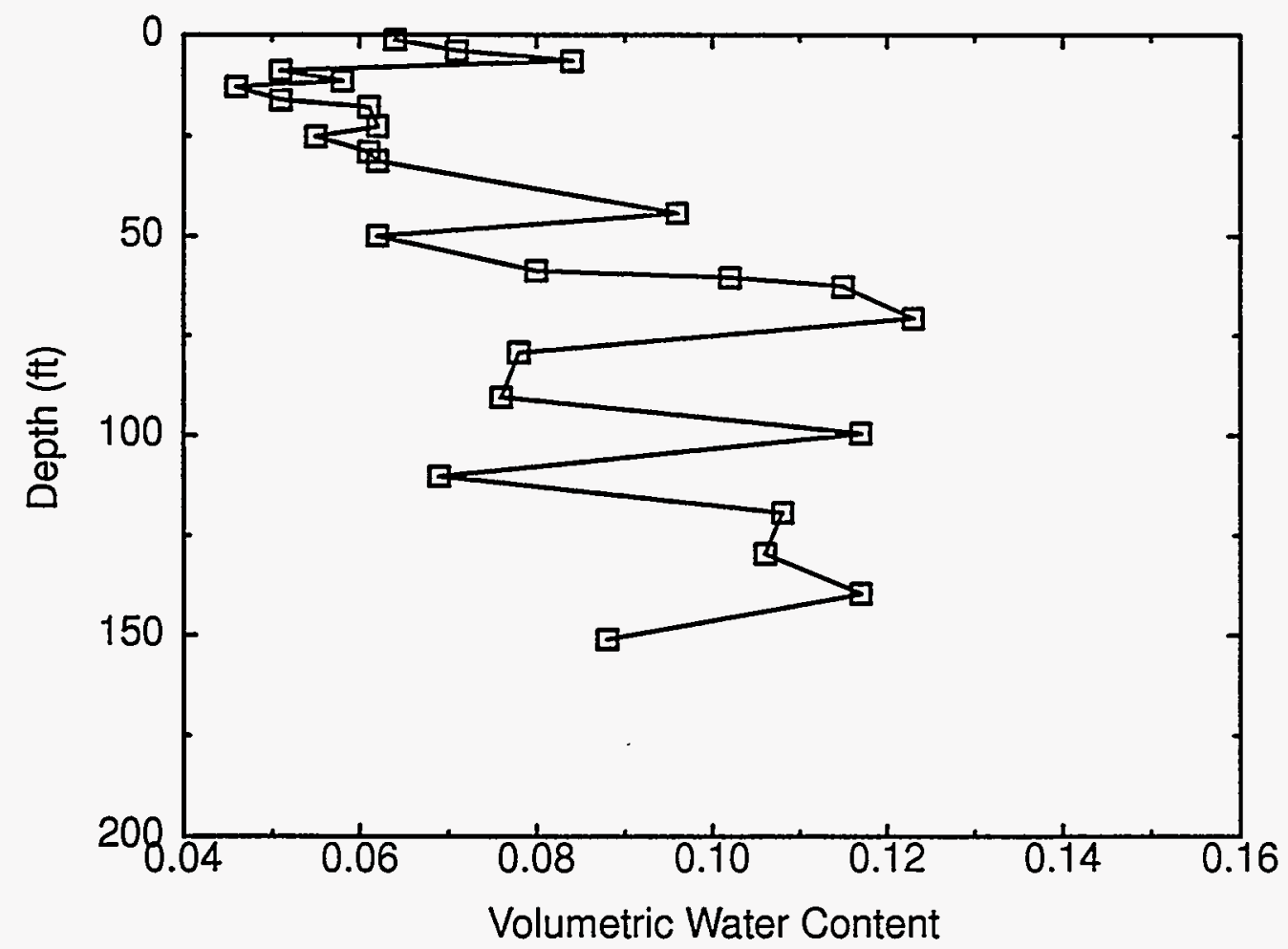

Figure 10. Depth profile of volumetric water content for borehole RP-2. 


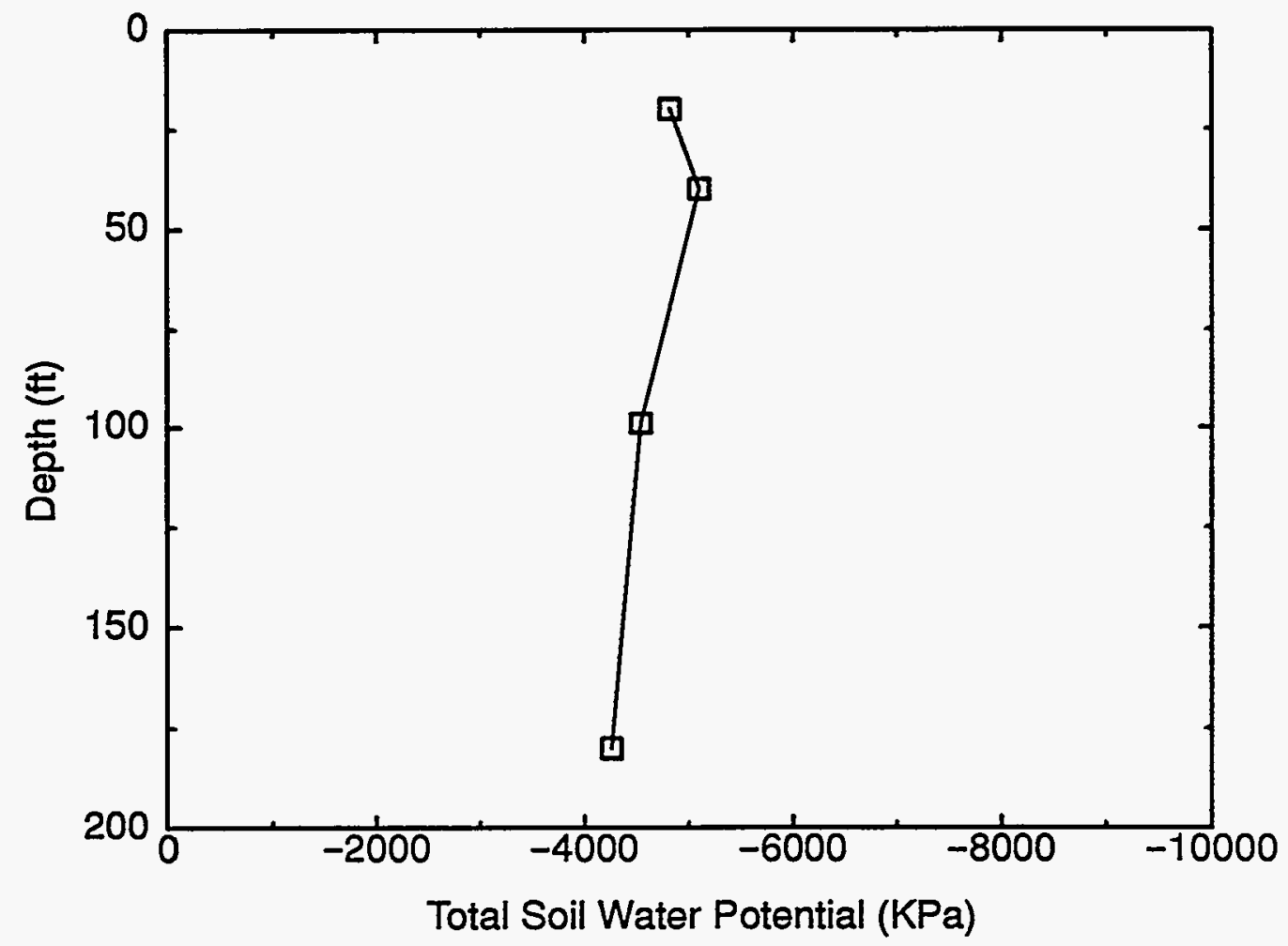

Figure 11. Depth profile of total soil water potential $(\mathrm{KPa})$ for borehole NN.

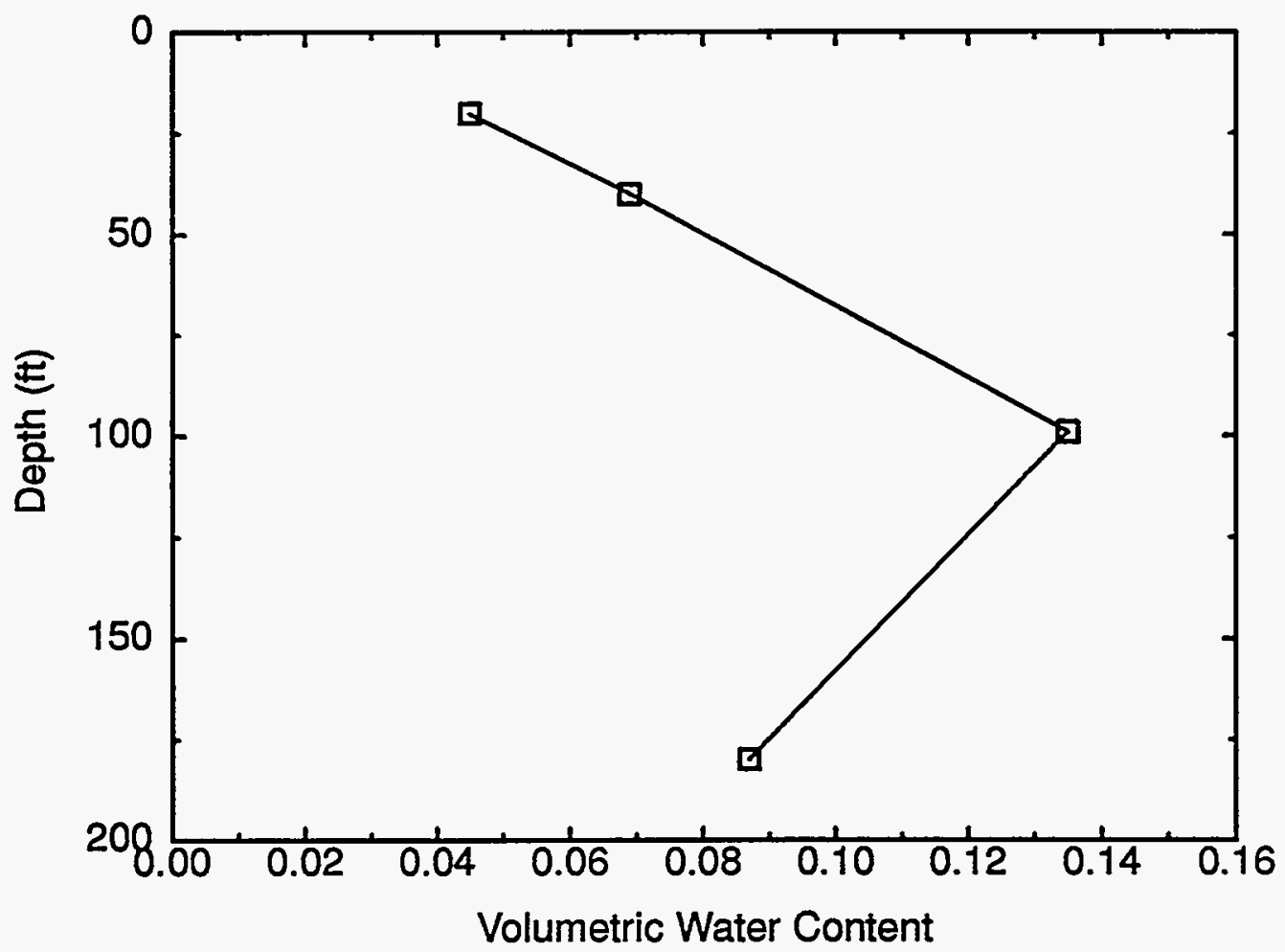

Figure 12. Depth profile of volumetric water content for borehole NN. 


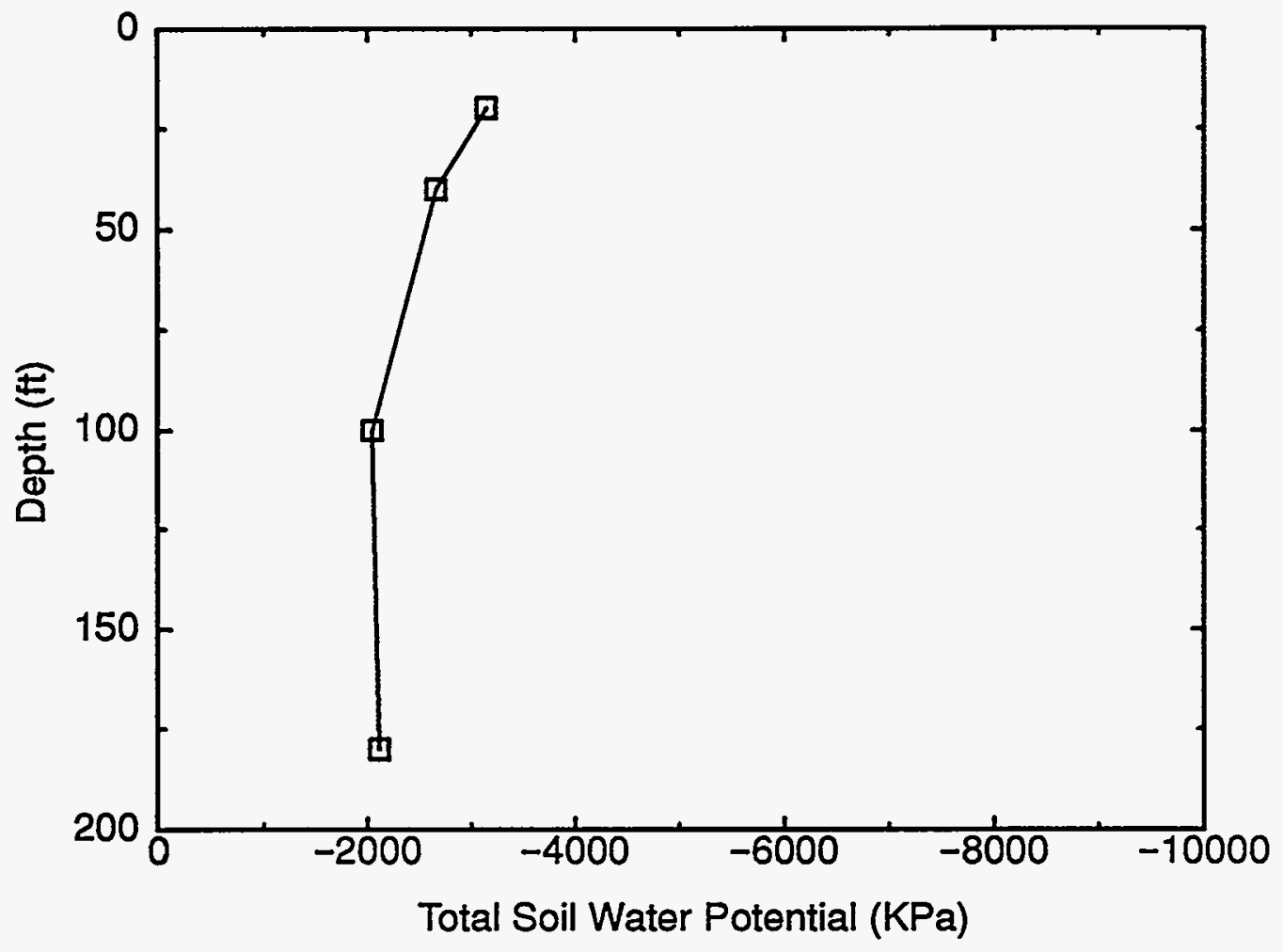

Figure 13. Depth profile of total soil water potential (KPa) for borehole NW.

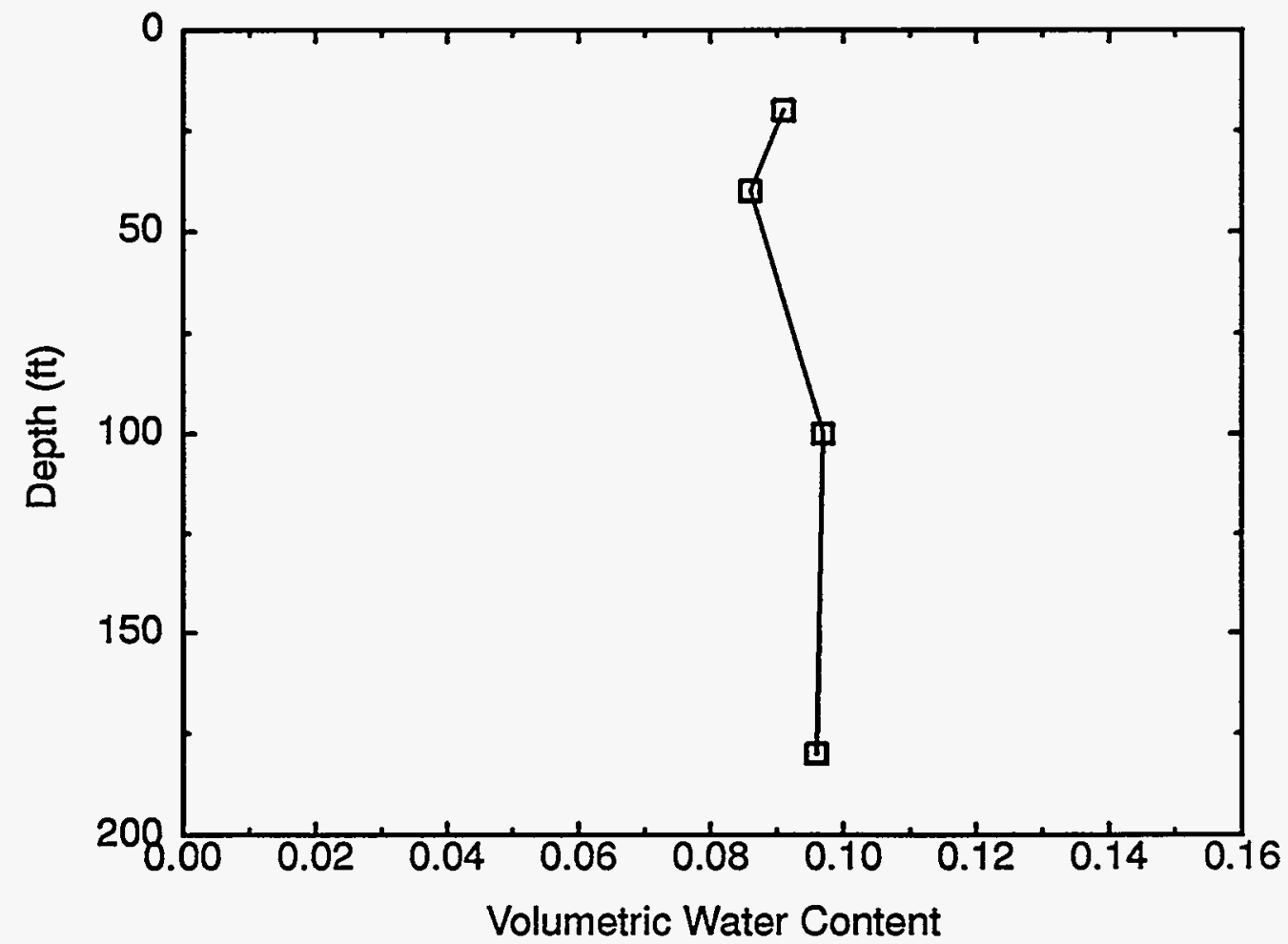

Figure 14. Depth profile of volumetric water content for borehole NW. 


\section{REFERENCES}

Allison, G.B., 1982, The Relationship Between ${ }^{18} \mathrm{O}$ and Deuterium in Water in Sand Columns Undergoing Evaporation. Journal of Hydrology, 55, 163-169.

Blake, G.R. and K.H. Hartge. 1986. Bulk Density.p. 363-366. In: A. Klute (ed.). Methods of Soil Analysis, Part 1. 2nd. ed. American Society of Agronomy (ASA), Soil Science Society of America (SSSA), Madison, Wis.

Campbell, G.S. and G.W. Gee. 1986. Water Potential: Miscellaneous Methods. p. 628-629. In: A. Klute (ed.). Methods of Soil Analysis, Part 1.2nd. ed. American Society of Agronomy (ASA), Soil Science Society of America (SSSA), Madison, Wis.

Dugan, J.P., J. Borthwich, R.S. Harmon, M.A. Gagnier, J.E. Glahn, E.P. Kinsel, S. MacLeod, J.A. Viglino and J.W. Hess, 1985. "Guanidine Hydrochloride Method for Determination of Water Oxygen Isotope Ratios and the Oxygen-18Fractionation Between Carbon Dioxide and Water at $25^{\circ} \mathrm{C}$," Anal. Chem. 57:1734-1736.

Gee, G.W., M.D. Campbell, G.S. Campbell, and J.H. Campbell. 1992. "Rapid measurement of low soil water potentials using a water activity meter". Soil Sci. Soc. Am. J., Vol. 56, p. 1068-1070.

Gonfiantini, R., 1981. "The Del-Notation and the Mass Spectrometric Measurements Techniques", International Atomic Energy Agency, Technical Report Series No. 210, Chapter 4, pp 35-84.

Graecen, E.L., G.R. Walker and P.G. Cook. 1989. Procedure for the Filter Paper Method of Measuring Soil Water Suction. Report 108, Division of Soil, CSIRO, Canberra, Australia.

Hillel, D. 1982. Introduction to Soil Physics. Academic Press, Inc. San Diego, CA. pp. 57-60 and 64-67.

Ingraham, N.L. and C. Shadel. 1992. A Comparison of the Toluene Distillation and Vacuum/Heat Methods for Extracting Soil Water for Stable Isotope Analysis. J. Hydrol., 140:371-387.

Kendall, C. and T.B. Coplen. 1985. "Multisample Conversion of Water to Hydrogen by Zinc for Stable Isotope Determination." Anal. Chem., Vol. 57, pp 1437-1440.

Reynolds Electrical \& Engineering Company (REECo). 1993a. Hydrologic Data for Science Trench Boreholes at the Area 5 Radioactive Waste Management Site, Nye County, Nevada. Special Project Section, Environmental Division, Reynolds Electrical and Engineering Co., Inc., Las Vegas, NV.

Reynolds Electrical \& Engineering Company (REECo). 1993b. Site Characterization and Monitoring Data from Area 5 Pilot Wells, Nevada Test Site, Nye County, Nevada. Special Project Section, Environmental Division, Reynolds Electrical and Engineering Co., Inc., Las Vegas, NV.

Revezs, K. and P.H. Woods. 1990. A Method to Extract Soil Water for Stable Isotope Analysis. J. Hydrol., 115:397-406.

Winograd, I.J. and W. Thordarson. 1975. Hydrologic and hydro-chemical framework, Southcentral Great Basin, Nevada-California, with special reference to the Nevada Test Site, Geol. Survey Prof. Paper 712-C. 
APPENDIX A 
TABLE A.1. Physical and hydrologic data for RP-1.

\begin{tabular}{|c|c|c|c|c|c|c|}
\hline $\begin{array}{l}\text { Sample } \\
\text { ID }\end{array}$ & Site No. & $\begin{array}{l}\text { Depth Interval } \\
(\mathrm{ft})\end{array}$ & $\begin{array}{l}\text { Total Potential } \\
\mathrm{CX}-2(\mathrm{KPa})\end{array}$ & $\begin{array}{l}\text { Grav. Water } \\
\text { Content }\end{array}$ & $\begin{array}{c}\text { Bulk Density } \\
\left(\mathrm{g} / \mathrm{cm}^{3}\right)\end{array}$ & $\begin{array}{c}\text { Vol. Water } \\
\text { Content }\end{array}$ \\
\hline 29643 & $R P-1$ & $0.25-.050$ & -1702 & 0.055 & 1.62 & 0.089 \\
\hline 29644 & RP-1 & $6.25-6.5$ & -7581 & 0.043 & 1.44 & 0.062 \\
\hline 29645 & $\mathrm{RP}-1$ & $9.25-9.5$ & -12832 & 0.030 & 1.68 & 0.050 \\
\hline 29646 & RP-1 & $10.75-11.0$ & -10108 & 0.016 & 2.27 & 0.037 \\
\hline 29647 & $\mathrm{RP}-1$ & $14.0-14.25$ & -6654 & 0.047 & 1.41 & 0.066 \\
\hline 29648 & RP-1 & $15.5-15.75$ & -5733 & 0.041 & 1.40 & 0.058 \\
\hline 29649 & $R P-1$ & $19.25-19.5$ & -6228 & 0.039 & 1.56 & 0.061 \\
\hline 29650 & $R P-1$ & $20.25-20.5$ & -4679 & 0.040 & 1.55 & 0.062 \\
\hline 29651 & $R P-1$ & $23.0-23.25$ & -4959 & 0.042 & 1.59 & 0.067 \\
\hline 29652 & $R P-1$ & $25.25-25.5$ & -6441 & 0.039 & 1.56 & 0.061 \\
\hline 29653 & $\mathrm{RP}-1$ & $29.25-29.5$ & -4679 & 0.053 & 1.33 & 0.070 \\
\hline 29654 & RP-1 & $31.0-31.25$ & -4260 & 0.041 & 1.35 & 0.055 \\
\hline 29655 & RP-1 & $44.25-44.5$ & -3148 & 0.054 & 1.72 & 0.092 \\
\hline 29656 & $\mathrm{RP}-1$ & $50.75-51.0$ & -3148 & 0.035 & 1.61 & 0.057 \\
\hline 29657 & RP-1 & $69.5-69.75$ & -2457 & 0.035 & 1.98 & 0.070 \\
\hline 29658 & RP-1 & $80.75-81.0$ & -2044 & 0.046 & 1.87 & 0.086 \\
\hline 29659 & RP-1 & $89.25-89.5$ & -1702 & 0.066 & 1.70 & 0.111 \\
\hline 29660 & $\mathbf{R P}-1$ & $100.5-100.75$ & -1565 & 0.055 & 1.69 & 0.093 \\
\hline 29661 & $\mathrm{RP}-1$ & $119.25-119.5$ & -1359 & 0.062 & 1.78 & 0.111 \\
\hline 29662 & RP-1 & $139.5-139.75$ & -1428 & 0.053 & 1.82 & 0.096 \\
\hline 29663 & RP-1 & $151.5-151.75$ & -1359 & 0.047 & 1.85 & 0.087 \\
\hline
\end{tabular}

*Sample 29646 contains one medium and one large $(8 \times 6 \times 6 \mathrm{~cm})$ rock. 
TABLE A.1. Physical and hydrologic data for RP-2.

\begin{tabular}{|c|c|c|c|c|c|c|}
\hline Sample ID & Site No. & $\begin{array}{l}\text { Depth Interval } \\
(\mathrm{ft})\end{array}$ & $\begin{array}{l}\text { Total Potential } \\
\mathrm{CX}-2(\mathrm{KPa})\end{array}$ & $\begin{array}{l}\text { Grav. Water } \\
\text { Content }\end{array}$ & $\begin{array}{c}\text { Bulk Density } \\
\left(\mathrm{g} r / \mathrm{cm}^{3}\right)\end{array}$ & $\begin{array}{l}\text { Vol. Water } \\
\text { Content }\end{array}$ \\
\hline 29724 & $\mathrm{RP}-2$ & $1.25-1.50$ & -7724 & 0.037 & 1.71 & 0.064 \\
\hline 29725 & $\mathrm{RP}-2$ & $4.0-4.25$ & -6654 & 0.043 & 1.64 & 0.071 \\
\hline 29726 & $R P-2$ & $6.5-6.75$ & -7223 & 0.049 & 1.72 & 0.084 \\
\hline 29727 & $\mathrm{RP}-2$ & $9.0-9.25$ & -8586 & 0.043 & 1.18 & 0.051 \\
\hline 29728 & $\mathrm{RP}-2$ & $11.5-11.75$ & -8442 & 0.033 & 1.77 & 0.058 \\
\hline 29729 & RP-2 & $13.0-13.25$ & -7724 & 0.027 & 1.70 & 0.046 \\
\hline 29730 & $R P-2$ & $16.25-16.5$ & -6087 & 0.040 & 1.26 & 0.051 \\
\hline 29731 & $R P-2$ & $18.0-18.25$ & -5945 & 0.038 & 1.61 & 0.061 \\
\hline 29732 & $R P-2$ & $22.75-23.0$ & -6370 & 0.039 & 1.60 & 0.062 \\
\hline 29733 & $R P-2$ & $25.25-25.5$ & -6299 & 0.034 & 1.62 & 0.055 \\
\hline 29734 & $R P-2$ & $29.0-29.25$ & -4959 & 0.042 & 1.45 & 0.061 \\
\hline 29735 & $R P-2$ & $31.25-31.5$ & -5100 & 0.035 & 1.79 & 0.062 \\
\hline 29736 & $R P-2$ & $44.25-44.5$ & -3564 & 0.054 & 1.79 & 0.096 \\
\hline 29737 & $R P-2$ & $50.0-50.25$ & -3564 & 0.034 & 1.81 & 0.062 \\
\hline 29738 & $R P-2$ & $58.75-59.0$ & -2871 & 0.051 & 1.58 & 0.080 \\
\hline 29739 & $R P-2$ & $60.5-60.75$ & -2251 & 0.059 & 1.71 & 0.102 \\
\hline 29740 & $R P-2$ & $62.75-63.0$ & -1907 & 0.077 & 1.49 & 0.115 \\
\hline 29741 & $R P-2$ & $70.75-71.0$ & -1770 & 0.081 & 1.52 & 0.123 \\
\hline 29742 & $R P-2$ & $79.25-79.5$ & -1702 & 0.046 & 1.71 & 0.078 \\
\hline 29743 & $\mathrm{RP}-2$ & $90.5-90.75$ & -1633 & 0.043 & 1.76 & 0.076 \\
\hline 29744 & $R P-2$ & $99.5-99.75$ & -1633 & 0.061 & 1.90 & 0.117 \\
\hline 29745 & RP-2 & $110.25-110.5$ & -3564 & 0.043 & 1.60 & 0.069 \\
\hline 29746 & RP-2 & $119.25-119.5$ & -1223 & 0.063 & 1.72 & 0.108 \\
\hline 29747 & RP-2 & $129.5-129.75$ & -1018 & 0.061 & 1.74 & 0.106 \\
\hline 29748 & $\mathrm{RP}-2$ & $139.5-139.75$ & -1223 & 0.068 & 1.71 & 0.117 \\
\hline 29749 & RP-2 & $151.0-151.25$ & -1018 & 0.056 & 1.58 & 0.088 \\
\hline
\end{tabular}


TABLE A.1. Physical and hydrologic data for AP-1.

\begin{tabular}{|c|c|c|c|c|c|c|}
\hline Sample ID & Site No. & $\begin{array}{c}\text { Depth Interval } \\
(\mathrm{ft})\end{array}$ & $\begin{array}{c}\text { Total Potential } \\
\text { CX-2 (KPa) }\end{array}$ & $\begin{array}{c}\text { Grav. Water } \\
\text { Content }\end{array}$ & $\begin{array}{c}\text { Bulk Density } \\
\left(\mathrm{g} / \mathrm{cm}^{3}\right)\end{array}$ & $\begin{array}{c}\text { Vol. Water } \\
\text { Content }\end{array}$ \\
\hline 29454 & AP-1 & $0.0-0.25$ & -746 & 0.066 & 1.64 & 0.109 \\
\hline 29455 & AP-1 & $2.75-3.0$ & -1839 & 0.069 & 1.57 & 0.109 \\
\hline 29456 & AP-1 & $6.5-6.75$ & -3981 & 0.047 & 1.58 & 0.074 \\
\hline 29457 & AP-1 & $10.75-11.0$ & -7366 & 0.032 & 1.66 & 0.053 \\
\hline 29458 & AP-1 & $13.75-14.0$ & -8442 & 0.024 & 1.85 & 0.044 \\
\hline 29459 & AP-1 & $16.0-16.25$ & -6228 & 0.029 & 1.60 & 0.046 \\
\hline 29460 & AP-1 & $19.25-19.5$ & -5240 & 0.037 & 1.53 & 0.057 \\
\hline 29461 & $\mathrm{AP}-1$ & $21.0-21.25$ & -5945 & 0.027 & 1.57 & 0.043 \\
\hline 29462 & AP-1 & $24.25-24.5$ & -4609 & 0.037 & 1.34 & 0.050 \\
\hline 29463 & $\mathrm{AP}-1$ & $26.75-27.0$ & -5875 & 0.034 & 1.48 & 0.050 \\
\hline 29464 & $\mathrm{AP}-1$ & $28.25-28.5$ & -6228 & 0.026 & 1.91 & 0.050 \\
\hline 29465 & $\mathrm{AP}-1$ & $40.5-40.75$ & -3842 & 0.045 & 1.65 & 0.074 \\
\hline 29466 & $\mathrm{AP}-1$ & $50.75-51.0$ & -3702 & 0.061 & 1.30 & 0.078 \\
\hline 29467 & AP-1 & $60.75-61.0$ & -3494 & 0.047 & 1.25 & 0.059 \\
\hline 29468 & AP-1 & $70.5-70.75$ & -2802 & 0.048 & 1.53 & 0.073 \\
\hline 29469 & $\mathrm{AP}-1$ & $81.0-81.25$ & -2802 & 0.067 & 1.60 & 0.107 \\
\hline 29470 & $\mathrm{AP}-1$ & $100.75-101.0$ & -2733 & 0.050 & 1.41 & 0.071 \\
\hline 29471 & $\mathrm{AP}-1$ & $109.75-110.0$ & -1839 & 0.069 & 1.67 & 0.116 \\
\hline 29472 & $\mathrm{AP}-1$ & $130.5-130.75$ & -1633 & 0.067 & 1.39 & 0.093 \\
\hline 29473 & $\mathrm{AP}-1$ & $159.75-160.0$ & -1565 & 0.078 & 1.60 & 0.124 \\
\hline 29474 & $\mathrm{AP}-1$ & $181.0-181.25$ & -2044 & 0.055 & 1.33 & 0.073 \\
\hline 29475 & $\mathrm{AP}-1$ & $200.5-200.75$ & -1496 & 0.055 & 1.41 & 0.078 \\
\hline 29476 & $\mathrm{AP}-1$ & $221.0-221.25$ & -1359 & 0.070 & 1.16 & 0.081 \\
\hline 29477 & $\mathrm{AP}-1$ & $240.5-240.75$ & -746 & 0.060 & 1.49 & 0.090 \\
\hline 29478 & $\mathrm{AP}-1$ & $259.5-259.75$ & -814 & 0.070 & 1.62 & 0.114 \\
\hline 29479 & AP-1 & $276.25-276.5$ & -3286 & 0.046 & 1.55 & 0.072 \\
\hline
\end{tabular}

*Sample 29557 contained one large $(8 \times 5 \mathrm{~cm})$ rock. 
TABLE A.1. Physical and hydrologic data for AP-2.

\begin{tabular}{|c|c|c|c|c|c|c|}
\hline Sample ID & Site No. & $\begin{array}{l}\text { Depth Interval } \\
\text { (ft) }\end{array}$ & $\begin{array}{l}\text { Total Potential } \\
\text { CX-2 (KPa) }\end{array}$ & $\begin{array}{c}\text { Grav. Water } \\
\text { Content }\end{array}$ & $\begin{array}{c}\text { Bulk Density } \\
\left(\mathrm{gr} / \mathrm{cm}^{3}\right)\end{array}$ & $\begin{array}{c}\text { Vol. Water } \\
\text { Content }\end{array}$ \\
\hline 29551 & $\mathrm{AP}-2$ & $0.5-0.75$ & -814 & 0.065 & 1.61 & 0.105 \\
\hline 29552 & AP-2 & $3.5-3.75$ & -1223 & 0.082 & 1.57 & 0.129 \\
\hline 29553 & AP-2 & $6.25-6.5$ & -2871 & 0.049 & 1.79 & 0.088 \\
\hline 29554 & AP-2 & $9-9.25$ & -3842 & 0.042 & 1.32 & 0.055 \\
\hline 29555 & AP-2 & $11-11.25$ & -8226 & 0.036 & 1.52 & 0.054 \\
\hline 29556 & $\mathrm{AP}-2$ & $13.5-13.75$ & -6016 & 0.029 & 1.82 & 0.052 \\
\hline 29557 & AP-2 & $15.25-15.5$ & -6654 & 0.017 & 2.19 & 0.037 \\
\hline 29558 & $\mathrm{AP}-2$ & $18-18.25$ & -4539 & 0.039 & 1.65 & 0.064 \\
\hline 29559 & $\mathrm{AP}-2$ & $20.25-20.5$ & -5170 & 0.037 & 1.62 & 0.061 \\
\hline 29560 & $\mathrm{AP}-2$ & $22.75-23$ & -5381 & 0.029 & 1.59 & 0.046 \\
\hline 29561 & AP-2 & $25.25-25.5$ & -4260 & 0.037 & 1.72 & 0.063 \\
\hline 29562 & AP-2 & $29.25-29.5$ & -4399 & 0.030 & 1.63 & 0.049 \\
\hline 29563 & AP-2 & $40.75-41$ & -3772 & 0.057 & 1.52 & 0.086 \\
\hline 29564 & AP-2 & $49.5-49.75$ & -2733 & 0.053 & 1.58 & 0.084 \\
\hline 29565 & AP-2 & $60.25-61$ & -3286 & 0.047 & 1.64 & 0.077 \\
\hline 29566 & AP-2 & $70-70.25$ & -2733 & 0.057 & 1.39 & 0.079 \\
\hline 29567 & AP-2 & $80.75-81$ & -2457 & 0.053 & 1.46 & 0.078 \\
\hline 29568 & AP-2 & $90.75-91$ & -2251 & 0.058 & 1.37 & 0.080 \\
\hline 29569 & $\mathrm{AP}-2$ & $110.75-111$ & -1770 & 0.067 & 1.46 & 0.098 \\
\hline 29570 & AP-2 & $120.5-120.75$ & -1839 & 0.061 & 1.67 & 0.101 \\
\hline 29571 & $\mathrm{AP}-2$ & $130.75-131$ & -1907 & 0.085 & 1.32 & 0.113 \\
\hline 29572 & $\mathrm{AP}-2$ & $149.5-149.75$ & -1702 & 0.067 & 1.84 & 0.123 \\
\hline 29573 & $\mathrm{AP}-2$ & $159.5-159.75$ & -1291 & 0.057 & 1.91 & 0.109 \\
\hline 29574 & AP-2 & $180.75-181$ & -1223 & 0.046 & 1.57 & 0.072 \\
\hline 29575 & AP-2 & $200.25-200.5$ & -1223 & 0.092 & 1.49 & 0.137 \\
\hline 29576 & AP-2 & $219.5-219.75$ & -746 & 0.053 & 1.74 & 0.091 \\
\hline 29577 & $\mathrm{AP}-2$ & $241.0-240.25$ & -1018 & 0.051 & 1.59 & 0.081 \\
\hline 29578 & AP-2 & $259.25-259.5$ & -882 & 0.051 & 1.91 & 0.097 \\
\hline 29579 & $\mathrm{AP}-2$ & $275.75-276.0$ & -814 & 0.052 & 1.80 & 0.093 \\
\hline
\end{tabular}


TABLE A.1. Physical and hydrologic data for NN-1 and NW-2.

\begin{tabular}{ccrcccc}
\hline Sample ID & Site No. & \multicolumn{1}{c}{$\begin{array}{c}\text { Depth Interval } \\
(\mathrm{ft})\end{array}$} & $\begin{array}{c}\text { Total Potential } \\
\text { CX-2 (KPa) }\end{array}$ & $\begin{array}{c}\text { Grav. Water } \\
\text { Content }\end{array}$ & $\begin{array}{c}\text { Bulk Density } \\
\left(\mathrm{gr} / \mathrm{cm}^{3}\right)\end{array}$ & $\begin{array}{c}\text { Vol. Water } \\
\text { Content }\end{array}$ \\
\hline 30619 & NN-1 & $20.0-20.25$ & -9164 & 0.025 & 1.81 & 0.045 \\
30620 & NN-1 & $40.0-40.25$ & -6299 & 0.044 & 1.55 & 0.069 \\
30621 & NN-1 & $99.5-99.75$ & -1839 & 0.084 & 1.60 & 0.135 \\
30622 & NN-1 & $180.5-180.75$ & -1428 & 0.052 & 1.69 & 0.087 \\
30623 & NW-1 & $19.75-20.0$ & -5311 & 0.055 & 1.66 & 0.091 \\
30624 & NW-1 & $39.75-40.0$ & -3148 & 0.052 & 1.65 & 0.086 \\
30625 & NW-1 & $100.25-100.5$ & -1830 & 0.051 & 1.88 & 0.097 \\
30626 & NW-1 & $180.25-180.5$ & -1702 & 0.049 & 1.93 & 0.096 \\
\hline \hline
\end{tabular}


APPENDIX B 
TABLE B.1. Stable isotope data for boreholes.

\begin{tabular}{|c|c|c|c|}
\hline SITE \# & $\begin{array}{c}\text { DEPTH } \\
\text { INTERVAL (ft) }\end{array}$ & $\begin{array}{l}\text { VSMOW } \\
\delta^{18} 0(\% / 00)\end{array}$ & $\begin{array}{l}\text { VSMOW } \\
\delta D(\% 0)\end{array}$ \\
\hline \multirow[t]{14}{*}{$\overline{\mathrm{AP}-2}$} & $0.25-0.50$ & -3.5 & -92 \\
\hline & $3.25-3.50$ & -2.3 & -64 \\
\hline & $6.50-6.75$ & -3.6 & -76 \\
\hline & $7.75-8.00$ & -4.1 & -76 \\
\hline & $13.25-13.50$ & -5.2 & -80 \\
\hline & $17.75-18.00$ & -4.6 & -78 \\
\hline & $21.50-21.75$ & -5.4 & -85 \\
\hline & $24.25-24.50$ & -4.9 & -81 \\
\hline & $39.25-39.50$ & -7.5 & -94 \\
\hline & $79.25-79.50$ & -10.9 & -105 \\
\hline & $129.25-129.50$ & $-12.0,-11.9$ & -108 \\
\hline & $181.00-181.250$ & -12.9 & -111 \\
\hline & $240.75-241.00$ & -13.0 & -111 \\
\hline & $275.50-275.75$ & -14.2 & -116 \\
\hline \multirow[t]{11}{*}{$\mathbf{R P}-2$} & $1.50-1.75$ & -8.4 & -100 \\
\hline & $4.25-4.50$ & -2.9 & $-74,-75$ \\
\hline & $6.75-7.00$ & -3.5 & -73 \\
\hline & $9.25-9.50$ & -4.2 & -76 \\
\hline & $11.25-11.50$ & -4.4 & -75 \\
\hline & $12.75-13.00$ & -5.1 & -79 \\
\hline & $17.75-18.00$ & -5.4 & -82 \\
\hline & $25.75-26.00$ & -6.7 & -90 \\
\hline & $45.0-45.25$ & -8.5 & -96 \\
\hline & $80.75-81.00$ & -12.5 & -112 \\
\hline & $150.75-151.00$ & -13.9 & -121 \\
\hline \multirow[t]{4}{*}{$\mathrm{NN}-1$} & $19.75-20.00$ & -6.6 & -89 \\
\hline & $39.75-40.00$ & -9.5 & -108 \\
\hline & $99.25-99.50$ & -13.3 & $-119,-120$ \\
\hline & $180.25-180.50$ & -14.6 & -126 \\
\hline \multirow[t]{4}{*}{ NW-1 } & $19.50-19.75$ & -6.9 & -81 \\
\hline & $39.50-39.75$ & -7.6 & -76 \\
\hline & $100.0-100.25$ & -8.1 & -71 \\
\hline & $180.0-180.25$ & -7.6 & -76 \\
\hline
\end{tabular}


TABLE B2. Carbon Isotope Data.

\begin{tabular}{lcccc}
\hline \multicolumn{1}{c}{ Well } & $\begin{array}{c}\text { Depth } \\
(\mathrm{m})\end{array}$ & $\begin{array}{c}\delta^{13} \mathrm{C} \\
(\% \circ \mathrm{PDB})\end{array}$ & $\begin{array}{c}\text { Percent Modern } \\
\text { Carbon }\end{array}$ & $\begin{array}{c}\text { Percent Modern } \\
\text { Carbon, Corrected* }\end{array}$ \\
\hline ST-1 & 33.5 & -7.0 & 23.04 & 18.9 \\
ST-1 & 30.8 & -6.9 & 19.33 & 17.2 \\
PW-1 & 54 & -8.0 & 26.69 & 24.5 \\
PW-2 & 30.2 & -6.2 & 13.71 & 12.6 \\
PW-2 & 14.6 & -5.2 & 25.59 & 19.4 \\
\hline
\end{tabular}

*This number is the measured percent modern carbon minus the carbon added during the soil washing procedure. 